\title{
繰り返し型工事における作業チーム編成の決定支援方法
}

\section{A DECISION SUPPORT METHOD FOR MANPOWER PLANNING IN REPETITIVE CONSTRUCTION WORKS}

\author{
金多 隆*, 長岡弘明**, 古阪秀三***, 山崎雅弘 ${ }^{* * * *}$, 鎌田元信***** \\ Takashi KANETA, Hiroaki NAGAOKA, Shuzo FURUSAKA, \\ Masahiro YAMAZAKI and Motonobu KAMADA
}

\begin{abstract}
In this paper, we discuss a new decision support method, by which a construction manager can get effective informations to solve following problems. Should the work be continued by the present organization of labor teams? If not, should it be reorganized now or when should it be? Simulation and optimization tools are developed to give the informations effective to solve the problems. Applying the method to some examples, the method is confirmed to be effective.
\end{abstract}

\author{
Keywords : simulation, decision making, manpower planning, repetitive construction work, \\ scheduling, construction management \\ シミュレーション, 意思決定, チーム編成, 繰り返し型, 工程計画, 工事管理
}

\section{1。席論}

超高層建築の建設工事において，繰り返し型工事が採用されてい る.繰り返し型工事をモテル化したものを図 1 に示す，横軸は工程， 繸軸は繰り返し回数を示す．それぞれのボックスは作業を示し，付 されたアルファベットはそれを担当するチームを示している．例え ばAチームはAがつけられた作業を下から上へと繰り返していく， 一般には，同図のように各作業は同期化されている。

工程変動は，同図におけるボックスの幅に乱れを生じさせる．全 ての作業がクリティカルパスになるため，1作業の遅れは，直ちに

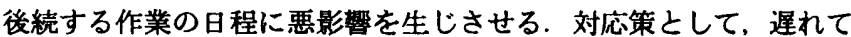
いる又は遅れそうな時点において，人員の投入や残業時間の増加を 行う等の措置がとられているが、これらは短期的視野に立つ手法と なっている．長期的な工事進行予測を行い，先行的に作業チ一ム編 成を検討するためのツールがなかったため，結果として稼僖率の低 下によるコストの上昇等の悪影響を生じている.

繰り返し型工事の計画・管理方法に関する研究として，文献 ${ }^{1) ~ 4 ~}$

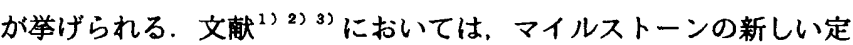
義を行うとともに，工事進行のシミュレーションツールが開発され， それらを用いた工程計画・管理の方法が提案されている. 文献 ${ }^{4}$ で
は、この方法を用いた時の作業チーム編成を，コストの観点から最 適化する方法が提案されている.

本研究ではこれらの方法を応用して，工事進行の途中において， 作業チームの再編成を行うかどうかの意思決定を支援する方法を提 案する．支援方法は，工事の管理者に将来の工事進行に関する情報 を与え，決定に合理性を持たせるものである.

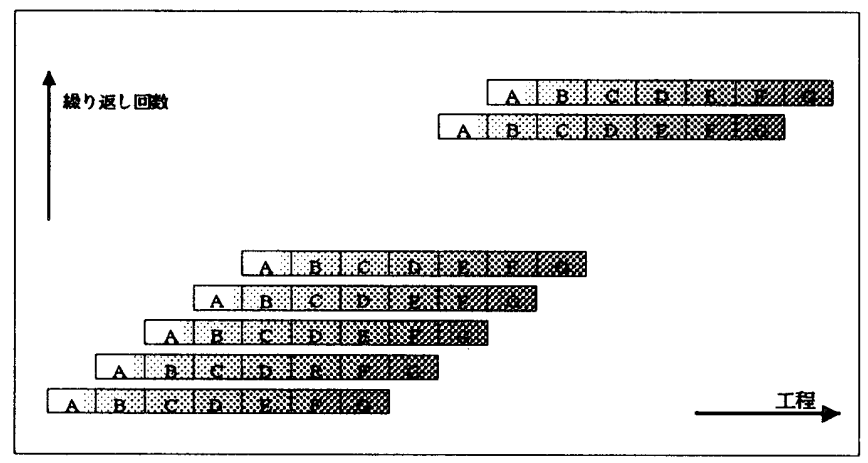

図 1 繰り返し型工事のモデル

\footnotetext{
* 京都大学大学院建築学専攻 研修員・博士 (工)

** 京都大学大学院建築学専攻 教授. 工博

*** 京都大学大学院建築学専攻 助教授 $\cdot$ 工博

**** 京都大学大学院建築学専攻 助手・博士 (工)

*****京都大学大学院建築学専攻 大学院生
}

Research Fellow, Dept. of Architecture and Architectural Systems, Kyoto University, Dr. Eng.

Prof., Dept. of Architecture and Architectural Systems, Kyoto University, Dr. Eng. Assoc. Prof., Dept. of Architecture and Architectural Systems, Kyoto University, Dr. Eng.

Instructor, Dept. of Architecture and Architectural Systems, Kyoto University, Dr. Eng.

Graduate Student, Dept. of Architecture and Architectural Systems, Kyoto University 


\section{2. 作業チーム編成の支援方法}

2.1 作業チーム編成と支援情報

シミュレーションを用いて将来の工事進行状況の可能な範囲を把 握し，これを支援情報として作業チーム編成についての意思决定を 行う.

工事進行中，工事管理者が作業チーム編成の意思決定を行うとき， 次の観点から検討を行う事が考えられる.

(1)現編成で工事を継続すべきであろうか？

(2)編成を変更するとしたとき，現時点で編成を変更をすべきであろ うか?

(3)現時点で編成を変更しないとしたら，今後のどの時点まで現編成 で工事を継続し，再度変更についての检討をすへきぎあろうか？ これらの検討において，工事管理者が考虑すへき第一優先課題は， 工事完了予定日内に確実に工事が完了することであり，第二にコス トの最小化である.これらのことを踏まえ，上記 3 項目の検討に対 する支援情報として、、図 2 に示す以下の 4 支援情報を考える. 次事 完了予定日以内に，100\%の確率で工事が完了するよう，作業チー 么編成を変更することを、単に「作業チーム編成の変更」と呼ぶ.

\支援情報 1 : 現時点の作業チーム編成で，最後まで工事を継続し た場合の, 工事完了予定日における工事完了の達成確率，及び工 事完了時までの労務コストの期待値の情報

\支援情報 2 : 現時点で「作業チーム編成の変更」を行った場合の, 工事完了時までの労務コストの期待値の情報

○支援情報 3 : 現時点では「作業チーム編成の変更」を行わずに工 事を継続し，指定日時を経過した時点の工事進行が最良の状況を 想定する。この時点で「作業チーム編成の変更」を行う場合の,
工事完了時までの労務コストの期待値の情報

○支援情報 4 ：現時点では「作業チーム編成の変更」を行わずに工 事を継続し，指定日時を経過した時点の工事進行が最悪の状況を 想定する.この時点で「作業チーム編成の変更」を行う場合の, 工事完了時までの労務コストの期待値の情報

2.2. 支援情報の作成

支援情報作成のため，以下の 2 つのッールを用いる.

(1)「工事進行シミュレーション」

工事が進行している時点を想定する. その時点の工事進行状況を 初期条件とし，作業チ一編成が与えられた時，工事完了予定日 における工事完了の達成確率と労務コストの期待値を算定する事 を考える.この算定を行うツールを「工事准行シミュレーション」 と呼び，その方法を 3 .で述へる.

(2)「作業チーム編成の最適化」

工事が進行しでいる時点で「作業チーム編成の変更」を行う事を 想定する．この時，その工事進行状況を初期条件とし，工事完了 時の労務コストの期待値を最小化するような作業チーム編成を行 うッールを「作業チーム編成の最適化」と呼び，その方法を 4 . で述べる.

各支援情報の中で、この 2 つツッールは図 3 に示すように用いら れる. 支援情報 1 においては，現時点までの編成を用いて，「工事 進行シミュレーション」を使って, 工事完了時における情報を得る. 支援情報 2 においては，「作業チーム編成の最適化」を用い，変更 する編成を決定し，同時にその編成での工事完了時における情報を 得る. 支援情報 $3 ， 4$ においては，「工事進行シミュレーション」 を指定日時まで適用し，得られた䊅果より最良と最悪の進行状況を

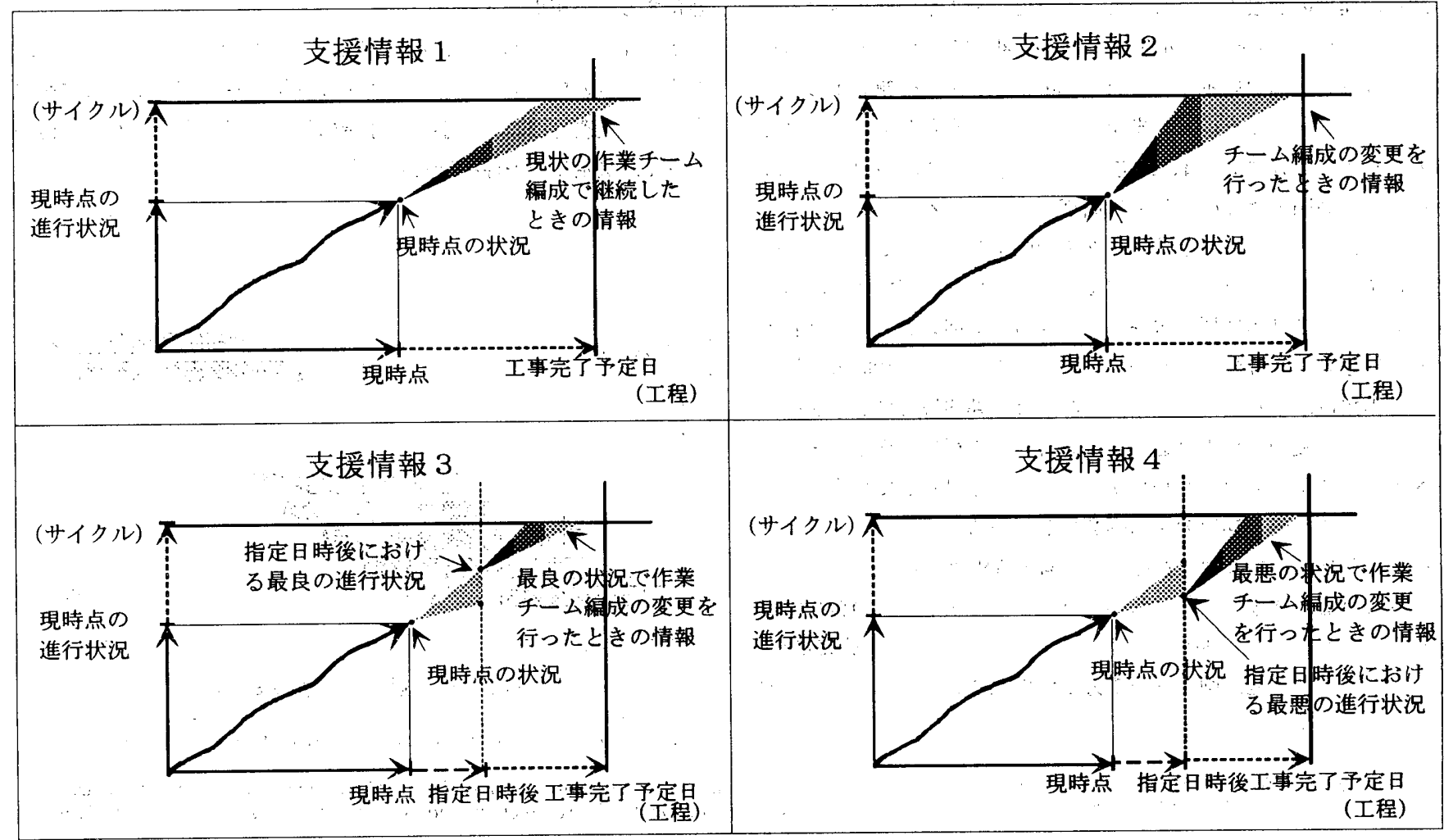

図2４４支援情報 


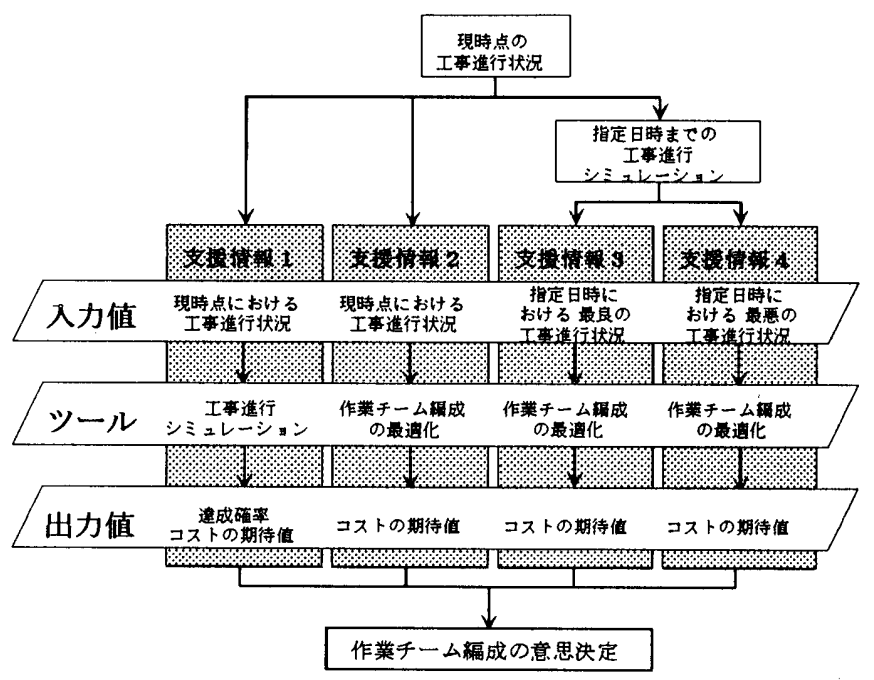

図 3 支援情報の作成

取り出す．指定日時における，最良又は最悪の進行状況を基に， 「作業チーム編成の最適化」を用い，その時点で変更すべき編成を 決定し，同時に工事完了時における情報を得る.

3.エ事進行シミュレーション

3.1 工事進行シミュレーションプログラム

モンテカルロ法を用いた工事進行シミュレーションが文献 ${ }^{122) 31 ~}$ で提案されており、その手順を以下に示す.

(1)初期条件の設定：工事進行状況を初期条件として入力する.

(2)チーム特性の設定 : 作業チームの作業所要日数の期待値之標準偏 差を設定する. チームの作業所要日数は正規分布によるものとす る.

(3)シミュレーションの実施：作業所要日数の確率分布にモンテカル 口法を用い，全サイクルでの各作業について，図4に示すように， 確定値としての所要日数を設定する. 確定値としての所要日数を 用いて、工程ネットワーク計算を行い，全工程の所要日数を算定 する。各作業チームの最初の作業開始時から最後の作業完了時ま でを拘束時間とし、これに各作業チームの人数と単価を乗じたも のを労務コストとする．この計算を 100 サンプルについて行う. (4)評価值の出力：100 サンプルの結果を用いて, 所要日数と達成確 率及び労務コストの期待值を情報として出力する.

モンテカルロ法を用いた作業所要日数の設定を図 5 に示す. 0 か ら 1 の範囲で乱数を発生させ，例えば，同図の例では 0.54 の乱数 を得る. 作業所要日数の確率分布関数を用いて, 乱数 0.54 に対応 する所要日数 4.08 日を得る. 工程計画・管理に用いる日数の最小 単位を 0.5 日とし，所要日数を 4.5 日と設定する.

3.2 チーム特性の設定

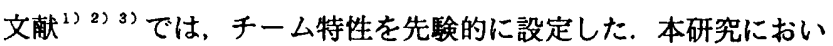
ては次のように設定する.

1 チームは 1 職種によって構成されているものとする.

等しい能力を持つn人が $\mathrm{T}$ 日で所与の仕事量Vを仕上げる時， $\mathrm{X}$ $=\mathrm{n} \mathrm{T}$ は正規分布 $\mathrm{N}\left(\mu, \sigma^{2}\right)$ に従うと仮定する． $\mu ， \sigma$ はそれ

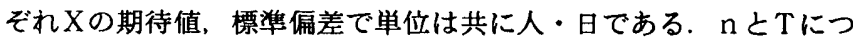
いて，片方が確定変数の時，他方が確率変数とする， $\mathrm{n}$ を確定変数
とするとき，確率変数 Tの分布は $\mathrm{N}\left(\mu / \mathrm{n}, \sigma^{2} / \mathrm{n}^{2}\right)$ に従う. $\mathrm{n}=1$ とすると $\mathrm{X}=\mathrm{T}$ であり，1人の作業員が仕事量 Vを行う時の 所要日数の期待值, 標準偏差が $\mu ， \sigma$ 之解釈することが出来る. 以 上より，等しい能力を持つ $\mathrm{n}$ 人からなる作業チームが仕事量 Vを行 う時, 所要日数の期待值 $\mu^{\prime}$ ，標準偏差 $\sigma^{\prime}$ を(1) 式で与える事が できる.

$$
\mu^{\prime}=\frac{\mu}{n} \quad, \sigma^{\prime}=\frac{\sigma}{n} \quad \cdots(1)
$$

作業員個々の能力の違いによる影響と習熟効果による影響を考虑 する．前者を作業員の熟練度 $\alpha$ ，後者を習熟度 $\beta$ と呼び以下のよう に定義する.

(1)熟練工，未熟練工の二つのタイプに作業員を大別する．同一の作 業を完了するための所要日数について, 熟練工と未熟練工の比が 1：1/aであるとする.このとき，熟練工の熟練度を 1 とし， 未熟練工の熟練度を $\alpha$ とする．例題に使用する各職種の熟練度 $\alpha$ を表 1 に示す.

(2)習熟勃果における習熟率は $95 \%$ ま1) とする.10 サイクル以上従 事した者はこれ以上習熟しないものとし、これを完全習熟と呼ぶ. 同一の作業に対し、完全習熟した作業員の所要日数 ${ }^{22} 1$ とお いたとき，完全習熟していない作業員の所要日数が 1 ／ $\beta$ である とき，習熟度を $\beta$ とする，完全習熟した作業員の習熟度は 1 であ る. 例題に使用する繰り返し回数と習熟度 $\beta$ との関係を図 6 に示 す.

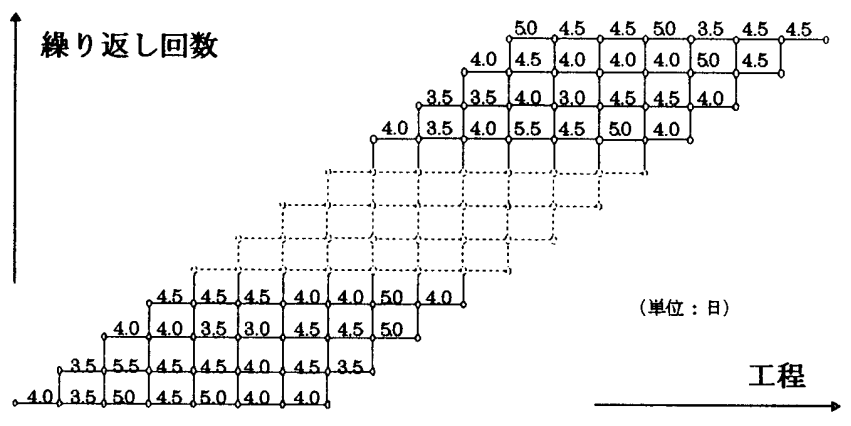

図4各作業の所要日数の一例

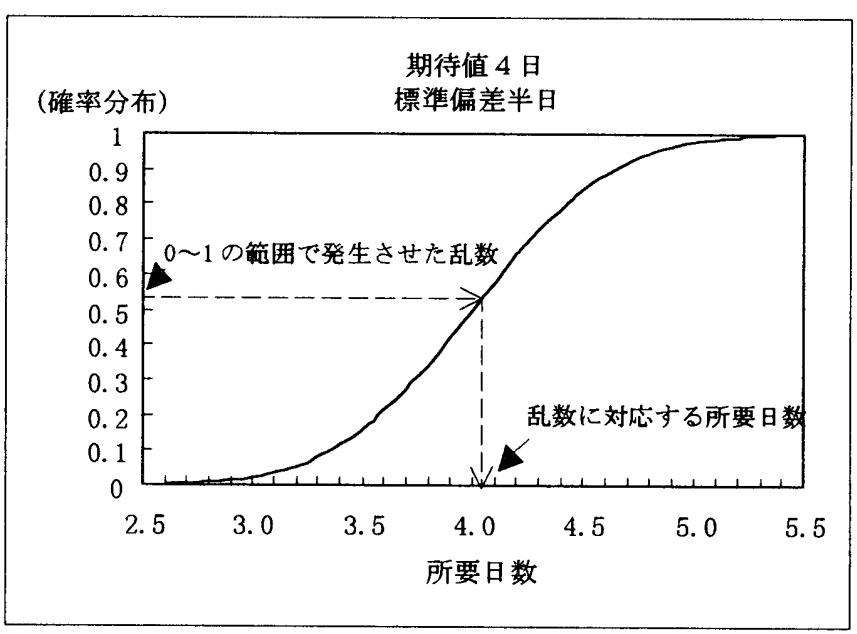

図 5 モンテカルロ法による所要日数の設定 


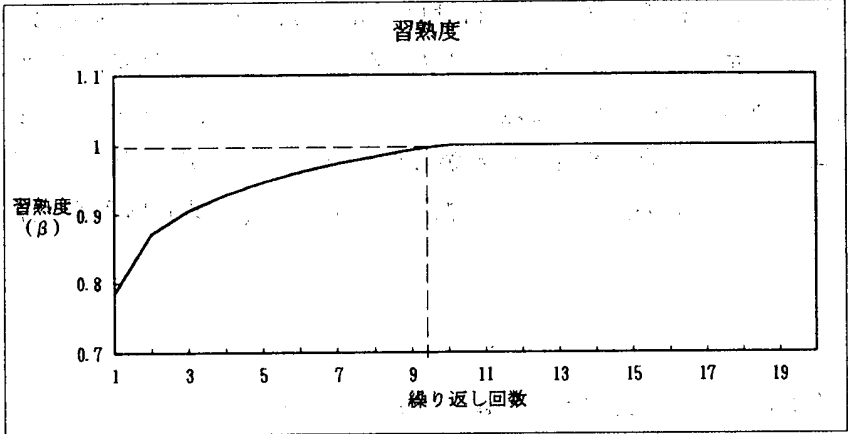

図 6 習熟度

熟練度と習熟度が各々異なる $\mathrm{n}$ 人の作業員で，作業チームが編成 されるときこの作業チームと同じ能力を持つ，完全習熟した熟練 工 $\mathrm{n}^{\prime}$ 人 ( $\mathrm{n}^{\prime}$ 'は実数) から成るチームを考える，n'を有効人数 と呼び，(2)式で求める事ができるものとする.

$$
\begin{aligned}
& n^{\prime}=\sum_{i=1}^{n} \alpha_{i} \cdot \beta_{i} \quad \cdots(2) \\
& n^{\prime}: \text { 有効人数 } \\
& n: \text { 構成人数 } \\
& \alpha i \text { 作業員 } i \text { 熟練度 } \\
& \beta_{i} \text { :作業員 } i \text { 習熟度 }
\end{aligned}
$$

熟練度，習熟度を考虑に入れた作業チーム特性は，(1)式における $\mathrm{n}$ の值に，(2) 式の有効人数 $\mathrm{n}$ 'の值を代入することで求めること ができる.

\section{4. 作業チーム編成の最適化}

「作業チーム編成の最適化」とはある時点の工事進行状況を初期 条件とし，工事完了予定日以内に工事完了の達成確率が $100 \%$ とな る編成のうち，労務コストの期待值を最小化する編成を行うことを いう，遭伝的アルゴリスムを用いて，作業チーム編成を最適化する 方法が文献"で提案されており，これを用いる.

遺伝的アルゴリズムを用いた最適化は，生物の遗伝のアナロジー を用いた最適化であり，遺伝子操作により世代を経るごとに，適合 度の高い個体を残す過程を模したものである. 遗伝子は各作業チー ムの編成内容に対応し，適合度は全作業チームの編成内容に対する 評価を示す．評価は，その編成で「工事進行シミュレーション」を 行った結果得られる, 工事完了予定日における工事完了の達成確率 と労務コストの期待值から求められる，適合度が十分高くないとき， 遗伝子操作を行い新たな編成を作る，適合度が十分高い編成となる まで、この作業を繰り返し行う。適合度の十分高い作業チーム編成 を最適解とする.

\section{5. 適用例題}

\section{1 例題の設定}

1 サイクルが7作業で構成されるサイクル工程を 40 サイクル繰 り返す工事を対象とし，工事完了予定日を204 日とする. 実際の工 事例を参考に作業員の特性である， $\mu ， \sigma$ 及び単価は表 1 の様に設

\begin{tabular}{|c|c|c|c|c|c|}
\hline $\begin{array}{c}\text { 于-台名 } \\
(\text { 職種) }\end{array}$ & $\begin{array}{c}\text { 作業者の } \\
\text { タイプ }\end{array}$ & 熟練度 $\alpha$ & $\begin{array}{c}\text { 期待值 } \mu \\
\text { (日) }\end{array}$ & $\begin{array}{c}\text { 標準偏差 } \sigma \\
\text { (日) }\end{array}$ & 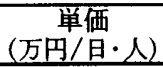 \\
\hline$A$ & 熟練工 & 1.00 & 16 & 1.8 & 1.6 \\
\hline (型枠工) & 未熟練工 & 0.67 & & & 1.3 \\
\hline $\begin{array}{c}\text { B } \\
\text { (鸷工) }\end{array}$ & $\begin{array}{l}\text { 熟練I } \\
\text { 未熟練工 }\end{array}$ & $\begin{array}{l}1.00 \\
0.67\end{array}$ & 24 & 4.5 & $\begin{array}{l}1.6 \\
1.3\end{array}$ \\
\hline $\begin{array}{c}\mathrm{C} \\
(\text { 鉄筋工) }\end{array}$ & $\begin{array}{l}\text { 熟練I. } \\
\text { 末熟綀I }\end{array}$ & $\begin{array}{l}1.00 \\
0.75 \\
\end{array}$ & 48 & 8.4 & $\begin{array}{l}1.5 \\
1.2 \\
\end{array}$ \\
\hline $\begin{array}{c}\text { D } \\
\text { (型枠工) }\end{array}$ & $\begin{array}{l}\text { 熟練工 } \\
\text { 未熟練工 }\end{array}$ & $\begin{array}{l}1.00 \\
0.67 \\
\end{array}$ & 16 & 1.8 & $\begin{array}{l}1.6 \\
1.3 \\
\end{array}$ \\
\hline $\begin{array}{c}\mathrm{E} \\
\text { (設備工) }\end{array}$ & $\begin{array}{l}\text { 熟練I } \\
\text { 未熟練工 }\end{array}$ & $\begin{array}{l}1.00 \\
0.71\end{array}$ & 40 & 2.4 & $\begin{array}{l}1.5 \\
1.2 \\
\end{array}$ \\
\hline $\begin{array}{c}F \\
\text { (土工) }\end{array}$ & $\begin{array}{l}\text { 熟練I } \\
\text { 末熟練工 }\end{array}$ & $\begin{array}{l}1.00 \\
0.79 \\
\end{array}$ & 44 & 4.8 & $\begin{array}{l}1.3 \\
1.1 \\
\end{array}$ \\
\hline $\begin{array}{c}\mathrm{G} \\
\text { (解体工) }\end{array}$ & $\begin{array}{l}\text { 熟練I } \\
\text { 未熟練工 }\end{array}$ & $\begin{array}{l}1.00 \\
0.71\end{array}$ & 20 & 4.8 & $\begin{array}{l}1.4 \\
1.1 \\
\end{array}$ \\
\hline
\end{tabular}
定する。 注3

工事開始時において「作業チーム編成の最適化」を行い, 求めら れた作業チーム編成で工事を開始寸る。50日目，および100日目
表 1 作業員の特性と単価

における工事進行がそれぞれ最良，最悪の場合を考え，これら合計 4 サンプルを用意する：各サンプルで 4 支援情報を作成し，作業于 一ム編成の変更を行うへきかどうかを検討する．支援情報 $3 ， 4$ の 指定日時は 30 日後とする.

5.2 意思决定

サンプル1〜4についての支援情報をそれぞれ図 $7^{\text {(4) }}$ に示し， 各サンプルにおける意思決定について検討する.

(1)サンプル 1

工事完了の達成確率が $100 \%$ となる日は工事完了予定日より，い ずれにおいてもやや早い，編成を装更した場合，工事完了日のばら つきの範囲が狭くなる，コスト面において，（支援情報 1) 乞(支 援情報 4)，（支援情報 1）>（支援情報 2 ）>（支援情報 3）で ある，以上の情報より，編成を変更すべきと考えられる：編成の変 更を現時点で行うか，30日後まで工事進行の状況を見るかは，優 劣をつけがたい，現時点で再度，例えば 15 日程度後の経過を指定 して情報 $3 ， 4$ を求め直して，意思決定する事も考えられる．又， 15 日程度工事進行を見て、その後改めて意思决定する事も考えら れる。

(2)サンプル 2

編成を変更した場合（支援情報 2〜4）は，工事完了の達成確率 が $100 \%$ となる日は編成を变更しない場合（支援情報 1）に比へて 早い，かつ，主事完了日のばらつきの範囲が狭くなる．コスト面に おいて，支援情報 2 のコストが最小である，以上の情報より，現時 点で編成を桨更すべきであると結論する事ができる.

(3)サンプル 3

編成を変更した場合，工事完了の達成確率が $100 \%$ となる日は編 成を変更しない場合に比へて遅くなる，コスト面において，支援情 報 2 のコストが最小である. コストを最優先する堨合には，現時点 で編成を変更をすべきであると結論つける事ができる.

(4)サンプル 4

編成を変更した場合，工事完了の達成確率が $100 \%$ となる日は編 成を変更しない場合に比へで早い，かつ，工事完了日のばらつきの 範囲が狭くなる，コスト面において，（支援情報 1) く（支援情報 4），（支援情報 1）>（支援情報 2 ）>（支援情報 3 ）である. 以上の情報より，編成を桨更すべと考えられる. 編成の変更を現 時点で行うか，30.日後まで工事進行の状況を見るかについては， 工事進行が最悪の揚合のリスクを考えると，前者が好ましいといえ る、しかし，支援情報 3 のコストが最小であることから，現時点で 

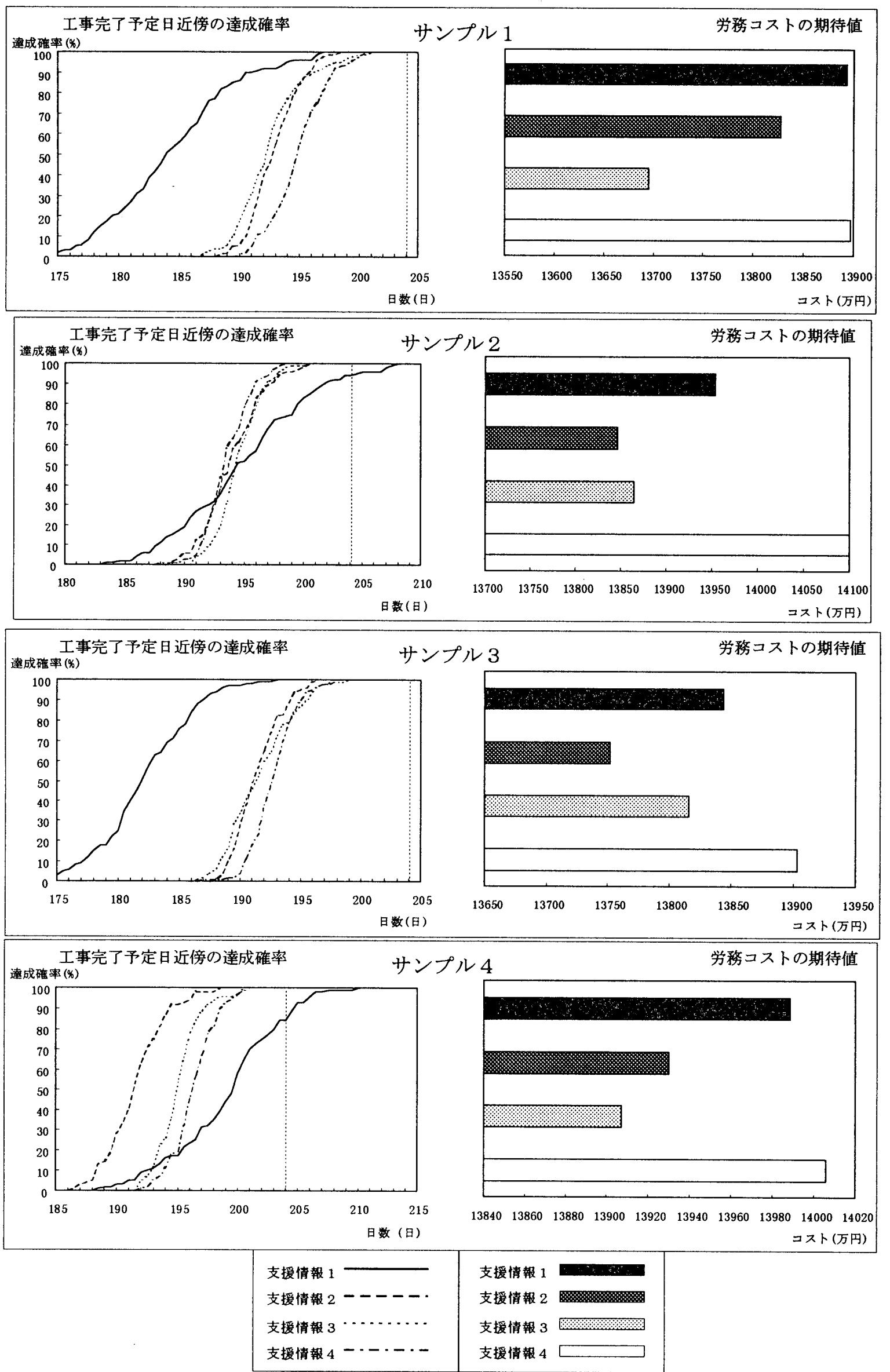

図 7 各サンプルの支援情報 
再度, 例えば 5 日程度後の経過を指定して情報 $3 ， 4$ を求め直して， 意思決定する事も考えられる．また，5日程度工事進行を見て，そ の後改めて意思決定する事も考えられる.

いすれのサンプルにおいても，作業チーム編成最道化をやり直し た場合の労務コストが編成を変更しない場合よりは低くなっている が，その程度によって編成の変更を行う時期についての意思決定に 工事管理者の裁量の余地のあることがわかる.

\section{6. 結論}

繰り返し型工事における作業進行の途中において，作業チームの 再編成を行うかどうかの意思決定を支援する方法を提示した．支援 は工事管理者に将来の工事進行に関する以下の 4 つの支援情報を与 える事で行う，1つは，現編成のままで工事を継続させたときの工 事完了時の情報であり，もう 1 つは，現時点で作業チ一ム編成の変 更を行った時の、工事完了時における情報である，残りの 2 つは， 指定日後のそれぞれ最良, 最悪の進行を想定し, その時に作業チー 么の変更を行った時の, 工事完了時における情報である. 適用例題 として 4 うの事進行状況を想定し，その結果，「現時点で作業于 一ム編成の変更をすべきである」，「現時点で変更を行うか，また は 5 〜 6 日進行を見てその時点で再度検討すべきである」等の、意 思決定を可能にしており，方法の有効性を示している.

\section{文中注釈}

注 1) 繰り返し回数が 2 倍になったときの累計平均所要日数の低減した率のこ とを言う。建設作業では， $75 \%$ 加ら $95 \%$ の竾囲であることが明らかになっ (いる. 6) в)

注 2) 習熟効果に関する従来の研究成果から, ほとんどの作業が対数線型モテ ルで表現できることが知られており，作業の繰り返し回数と累計平均所要日 数の関係は次式で表すことができる． ${ }^{5)}$

$A c=t 1 x^{-n}$

ただし、

$A c:$ 累計平均所要日数

$t_{1}:$ 第一回目の所要日数

$x:$ 繰り返し回数

$n:$ 習熟係数 (習熟率95\%で0.074)

上式によりサイクル毎の所要日数を計算する

注 3)3.2 の仮定より次のことが言える. Tを確定変数とするとき, 確率変数 $\mathrm{n}$ の分布はN $(\mu / \mathrm{T}, \sigma 2 / \mathrm{T} 2)$ に従う.

下の図は, 文献 ${ }^{11}$ から引用したある超高首 $\mathrm{R}$ C 造建築の新筑工事の際の鳥 工の投入作業員人数の変動の実例である. この例では，所要日数を 4 日にな

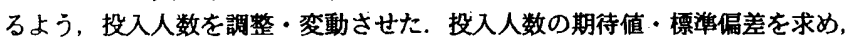
上の式にて $\mathrm{T}=4$ とおくことにより， $\mu ， \sigma$ を求めることが出来る. 表 1 の $\mu, \sigma$ は各職種に関して, この方法で求めた. 又, 個人の単価は, 文献 ${ }^{7} の$

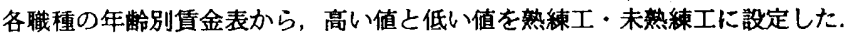

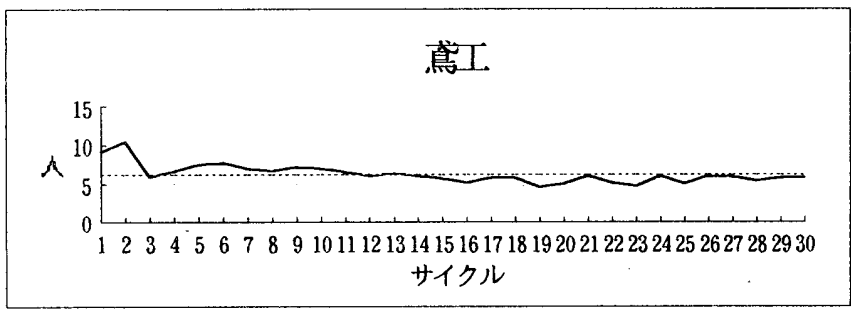

注 4) サンプル 2，4 の支援情報 1 は，工事完了予定日である204 日における 工事完了の達成確害が $100 \%$ となるように, 工事開始時に作業子一么編成の 最適化を行った結果である. しかし, サンプル $2 ， 4$ のシミュレーション結 果（図7）における達成確率は100\%を下回っている。これは, シミュレー ション手法上の限界によるものである。

\section{参考文献}

1) 朴烟根：綝り返し型建策工事における工程計画・管理に関する研究， 京都大学学位論文, pp.95-161，1995.5

2）金多，長岡，古阪，朴：稆り返し型工事におけるマイルストーンを用い た工程計画・管理方法, 日本建築学会大会学術講演梗概集, 1996.9

3) 吉田, 長岡, 古阪, 朴: 稆り返し型工事における概略工程のモテル化と シミュレーション, 日本建筑学会第 11 回建筑生库と管理技術シンポジウム 論文集，pp.197-202， 1995.7

4) 安川, 長岡, 古阪, 山猗, 金多: 繰り返し型工事におけるチ一ム編成の 最適化への遗伝的アルゴリズムの適用, 日本建築学会大会学術講演梗概集, 1996.9

5）松本信二：建筑施工の計画方法に関する研究－MACによる作業計画方 法の考察一，清水建設研究報告別冊，第 21 号, pp.58-61， 1987.4

6) 岩下, 古川, 古阪, 透藤, 吉田, 湯谷, 星野: 超高層集合住宅における 生産管理に関する研究（その4）－工数低減とサイクル工程の変更一，日本 建筑学会第 5 回建築生産と管理技術シンポジウム論文集, pp.163-168, 1989.7

7）経济調查会，楮算資料，1995 年 1 月号 